\title{
Redox Flow Batteries for Hybrid Electric Vehicles: Progress and Challenges
}

\author{
Mohd R. Mohamed ${ }^{1,2}$, Graduate Member, IEEE, Suleiman M. Sharkh ${ }^{3}$ and Frank C. Walsh ${ }^{4}$ \\ Energy Technologies Research Group, \\ School of Engineering Sciences, University of Southampton, Highfield, Southampton SO17 1BJ, UK. \\ ${ }^{2}$ Faculty of Electrical \& Electronics Engineering, \\ Universiti Malaysia Pahang, Lebuhraya Tun Razak, 26300 Kuantan, Pahang, MALAYSIA. \\ 19mrm2v07@soton.ac.uk, ${ }^{3}$ suleiman@soton.ac.uk, ${ }^{4}$ F.C.Walsh@soton.ac.uk
}

\begin{abstract}
Electric vehicles have been the focus of much research over the last two decades as the world has sought improved energy utilization and reduced emissions. However, the lengthy charging time, modest range and relatively sluggish performance of batteries have restricted the commercialization of electric vehicles. Hybrid propulsion can overcome most of these shortcomings, with improved energy efficiency and reduced emissions compared to conventional internal combustion engine vehicles (ICEVs). Nonetheless, energy storage issues are still critical. Redox flow batteries (RFB), which continue to mature, have the potential to be fast recharging contenders. Refuelling is possible by rapid pumping of the reactants into the batteries' tanks. Another feature of RFBs that makes them attractive for EV applications is the separation, in terms of physical location and sizing, of the energy and power components. This adds a degree of flexibility that allows the optimization of the power and energy components for a specific vehicle configuration and performance.

This paper concisely reviews RFBs and assesses their potential as a power source for hybrid electric vehicles. Experimental performance data from a $100 \mathrm{~cm}^{2}$ laboratory, unit cell, allvanadium redox flow battery (V-RFB) are presented. Based on these results, the size and performance of a V-RFB, suitable for a series hybrid electric vehicle, are estimated and compared with lithium-ion and conventional lead-acid alternatives. The results suggest that V-RFB performance could be improved to match that of the conventional lead-acid, with the added advantage of very rapid recharging.
\end{abstract}

Index Terms- Redox flow battery, Road vehicle electric propulsion, Road vehicle power systems

$\begin{array}{ll}\text { Abbreviations } \\ \text { AER } & \text { All electric range } \\ \text { BEV } & \text { Battery-powered electric vehicle } \\ \text { EV } & \text { Electric vehicle } \\ \text { EGM } & \text { Electric generator / motor } \\ \text { FC } & \text { Fuel cell } \\ \text { HEV } & \text { Hybrid electric vehicle } \\ \text { ICEV } & \text { Internal combustion engine vehicle } \\ \text { PHEV } & \text { Plug-in hybrid electric vehicle } \\ \text { RFB } & \text { Redox flow battery } \\ \text { V-RFB } & \text { All-vanadium redox flow battery }\end{array}$

This work was supported by The Malaysian Ministry of Higher Education and Universiti Malaysia Pahang (UMP), Malaysia.

\author{
Symbols \\ $\Delta c \quad$ Change in reactant concentration in the electrolyte \\ $\eta_{C} \quad$ Charge efficiency \\ $\eta_{E} \quad$ Energy efficiency \\ $\eta_{P} \quad$ Power efficiency \\ $\eta_{V} \quad$ Voltage efficiency \\ E Energy \\ F $\quad$ Faraday constant \\ I Current \\ j Current density \\ M Molar mass \\ $q \quad$ Electrical charge \\ $V \quad$ Volume of electrolyte \\ $V_{\text {cell }} \quad$ Cell voltage \\ $V_{\text {reference }}$ Open-circuit cell voltage of the monitoring cell \\ $z \quad$ No. of electrons transferred during redox reaction
}

\section{INTRODUCTION}

Increasing environmental awareness and heightened concerns over recent fossil fuel supplies and their price continue to stimulate research aimed at alternative resources and energy efficiency, including research into hybrid electric vehicles (HEVs). Figures released by BP in 2007 [1] show that crude oil prices have been on an upward path for more than 6 years, rising by $11 \%$ in 2007 alone. During 2008, the price of oil nearly doubled within a very short period then fell sharply due to the worldwide economic recession caused by the credit crunch. In recent years there has been a huge increase in demand for energy and transport [2] with numerous developing countries experiencing an upward trend of annual per capita energy use and an increase in people mobility to an average of $1.1 \mathrm{~h} \mathrm{day}^{-1}$ [3]. Amongst the claims and counter claims of 'peak oil' theory supporters [4] and opponents [5], there seems to be an emerging perception that the World will soon be facing an acute oil shortage.

Several hybrid electric vehicles are now in production, with rising sales and range of specifications. Most of the current production vehicles are light hybrids, with most of the energy and power supplied by the engine and the petrol tank. A relatively small electric motor/generator and battery are used to primarily provide load levelling, with no need to charge from an external source. As oil and gas supplies diminish, and 
electricity generation shifts towards alternative sources, the degree of hybridization needs to be shifted toward larger electric machines and batteries that require charging from external sources. In this case, slow charging batteries will be a major obstacle. This situation has encouraged research into hydrogen fuel cells attracted by the possibility of rapid refuelling with hydrogen produced using electricity supplied by any source.

Redox flow batteries (RFBs) which use flowing liquid electrolytes, have the potential to be attractive alternatives to hydrogen fuel cells. RFBs allow a degree of separation between power and energy components. This flexibility enables the optimisation of both components separately to suit specific vehicle performance and configuration. Compared to hydrogen fuel cells, RFBs have several advantages including low material cost, easier handling and storage of the liquid reactants compared to hydrogen and higher power density. But the energy density of current RFBs is significantly lower than that of fuel cells.

This paper considers the use of RFBs for powering automotive vehicles; reviewing the current state-of-the art and highlighting future technological challenges. In section II, the principle of operation of RFBs, a brief overview of RFB systems and their figures of merit are provided. The status and trends in automotive industry are considered in section III, together with a focus on hybrid electric vehicles (HEVs). Section IV describes the development of a vanadiumvanadium redox flow battery $\mathrm{V}$-RFB in our laboratory and presents performance results of a $100 \mathrm{~cm}^{2}$ unit cell. Based on those performance results, a scaled-up V-RFB suitable for a series hybrid electric vehicle developed in our laboratory [6] is estimated and compared to lithium-ion and conventional leadacid alternatives. Section $\mathrm{V}$ discusses the remaining technical challenges facing RFBs and identifies further work to overcome these challenges.

\section{REDOX FLOW BATTERIES}

With the advantages of moderate cost, modularity, transportability and flexible operation [7], RFBs could provide a promising technology that could be utilized for a system that meets the pulse power requirements of a vehicle. In addition, the reactants and the electrolyte (henceforth referred to as 'the electrolyte') are stored separately (except for flooded soluble lead RFB which has a single electrolyte), which eliminates self-discharge, prolongs the life span of the battery [8] and reduces maintenance and lowers operating cost. Rapid response from idle condition and high rate output performance over short time period [9] also present an outstanding advantage for HEV applications.

Over the last few years, many types of RFB have been considered, including bromine-polysulfide, vanadiumvanadium, vanadium-bromine, iron-chromium, zinc-bromine, zinc-cerium, and soluble lead RFBs. They were mainly introduced for load levelling, power quality control, and system stability [10-13].

An RFB is an electrochemical energy storage device, in which system power and storage capacity can be largely decoupled. The former is determined by the design of the cell stack and its size, while the size of the storage tanks, the volume of electrolyte and the concentration of reactant defines the latter. Fig. 1 shows a concept diagram for the RFB. The battery consists of two electrochemical half-cells (the positive and negative half-cells) separated by an ion exchange membrane. A pump is used to circulate the electrolyte through the cell stack. In the soluble lead-acid RFB a single electrolyte is used without a membrane.

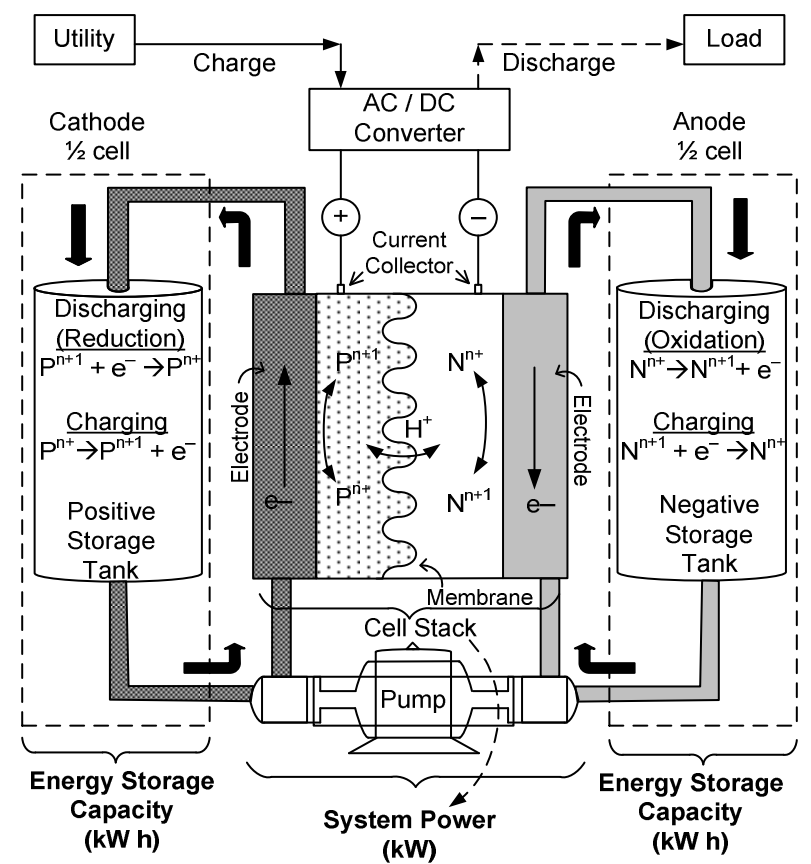

Fig. 1. Single stack flow circuit showing the principle of an RFB system

In general, RFBs are more similar to FCs except that the electrolyte in FC system remains within the cell stack, whereas electrolyte in RFB flows through the cell stack to allow redox reaction takes place. Table 1 provides general comparison for battery technologies.

Electrochemical redox reactions take place at each electrode. The membrane allows the transport of protons to maintain the electrical neutrality and electrolyte balance but reduce the transport of reactive species between the anode and cathode compartments to a minimum. Electrons flow (reversibly) via the external circuit to complete the electrochemical reaction and produce electricity. The redox reactions are illustrated in Fig. 1 with the $\mathrm{P}$ and $\mathrm{N}$ ions in both states of charge for each anode and cathode $1 / 2$ cells.

The RFB can be rapidly recharged by draining the discharged electrolyte solutions and replacing them with a fully charged electrolyte. One could envisage this to be done at rapid refuelling/recharging stations in a similar fashion to petrol stations. Furthermore, system power is determined by acceleration performance of the desired vehicle, whereas the energy storage capacity is decided by the range travelled. The decoupling of the power and energy components of a RFB 
provides an additional degree of freedom to the vehicle designer. In addition to flexibility of storage tanks and cell stack physical layout, the designer can optimise the size of the power and energy components to suit the configuration of the vehicle and meet desired performance specifications [14]. In conventional batteries, power and energy capacity are directly tied, which is a limitation for a vehicle designed for performance but a short travel range or vice versa.

Several figures of merit have been used to characterize the performance of RFBs [7] (Fig. 2) including voltage-, coulombic-, power- and energy efficiencies. Table 2 compares several figures of merit for different RFBs with conventional lead-acid, lithium-ion and nickel metal hydride batteries. Some of the data has been compiled from [7] and [15].

TABLE 1

GENERAL COMPARISON FOR DIFFERENT TYPES OF BATTERIES (adapted from [7])

\begin{tabular}{|l|l|l|l|}
\hline \multicolumn{1}{|c|}{$\begin{array}{c}\text { Types of } \\
\text { batteries }\end{array}$} & Products & \multicolumn{1}{c|}{$\begin{array}{c}\text { Electrolyte } \\
\text { condition }\end{array}$} & \multicolumn{1}{c|}{ Energy stored } \\
\hline $\begin{array}{l}\text { Static battery } \\
\text { (Secondary } \\
\text { battery) }\end{array}$ & $\begin{array}{l}\text { Active } \\
\text { electrode } \\
\text { material }\end{array}$ & $\begin{array}{l}\text { Static and held within } \\
\text { the cell }\end{array}$ & $\begin{array}{l}\text { Within electrode } \\
\text { structure and could be } \\
\text { reversible }\end{array}$ \\
\hline RFB & $\begin{array}{l}\text { Aqueous } \\
\text { electrolytes } \\
\text { within } \\
\text { reservoirs }\end{array}$ & $\begin{array}{l}\text { Electrolyte flows } \\
\text { through the cell }\end{array}$ & $\begin{array}{l}\text { Within redox species } \\
\text { that re-circulate } \\
\text { through the cell and } \\
\text { reversible electrode } \\
\text { reactions }\end{array}$ \\
\hline FC & $\begin{array}{l}\text { Gaseous or } \\
\text { liquid fuel } \\
\text { plus air }\end{array}$ & $\begin{array}{l}\text { Solid polymer or } \\
\text { ceramic acts as solid } \\
\text { electrolytes within cell }\end{array}$ & $\begin{array}{l}\text { Within reactants } \\
\text { externally to the cell } \\
\text { and non-reversible }\end{array}$ \\
\hline
\end{tabular}

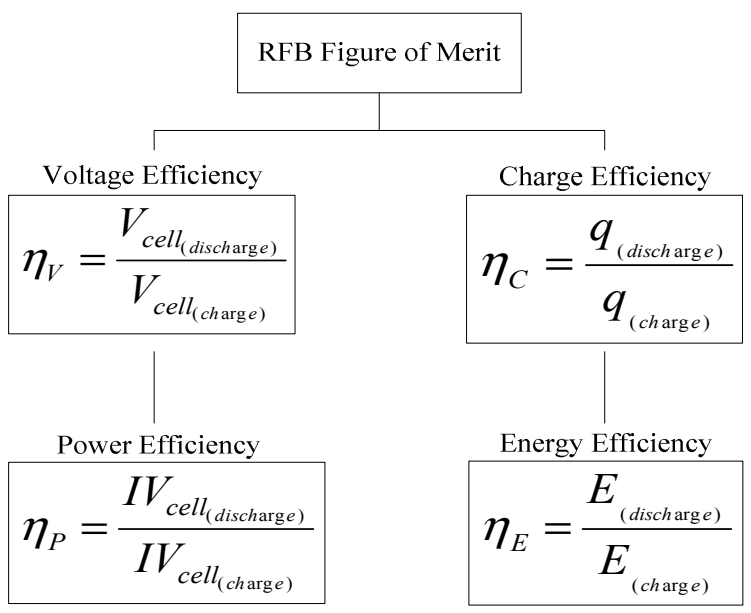

Fig. 2. Figures of merit for RFBs

It is clear from Table 2 that the current generation of RFBs is inferior to conventional batteries. The energy and power densities are approximately one third of conventional leadacid. But this performance gap has been reducing over recent years as a result of intensive research on RFBs. This trend is likely to continue in the future with the enhancement of membrane porosity, three-dimensional electrodes, highly catalytic electrodes, high linear velocities and good turbulence promoters [7].
TABLE 2

A COMPARISON OF RFBS AND CONVENTIONAL BATTERIES

\begin{tabular}{|c|c|c|c|c|c|c|}
\hline Batteries & $\% \eta_{v}$ & $\% \eta_{C}$ & $\% \eta_{E}$ & $\mathbf{W h} \mathbf{L}^{-1 *}$ & $\mathbf{W} \mathbf{L}^{-1 \text { ** }}$ & $\begin{array}{c}j \\
/ \mathbf{m A} \mathbf{c m}^{-2} \\
\end{array}$ \\
\hline Bromine-polysulphide & 75 & - & 77 & $20-35$ & 60 & 60 \\
\hline Vanadium-vanadium & 81 & 90 & 73 & $20-35$ & $60-100$ & $60-100$ \\
\hline Iron-chromium & 82 & - & 66 & $20-35$ & 6 & 10 \\
\hline Vanadium-bromine & 80 & 83 & - & $20-35$ & 50 & 50 \\
\hline Zinc-/bromine & - & - & 80 & $20-35$ & 40 & 40 \\
\hline Zinc-cerium & - & 83 & - & $20-35$ & 50 & 50 \\
\hline Soluble lead-acid & - & 79 & 60 & $20-35$ & 25 & 25 \\
\hline Conventional lead-acid & - & - & 68 & $60-80$ & 230 & - \\
\hline Lithium-ion & - & 100 & 80 & $150-200$ & 275 & - \\
\hline Nickel metal hydride & - & - & 75 & $100-150$ & 330 & - \\
\hline
\end{tabular}

"For RFBs energy density figure is for electrolyte tanks only.

${ }^{* *}$ For RFBs the power density figures exclude cell stack volume

\section{AUtOMOTIVE INDUSTRY STATUS AND TRENDS}

In this section, a brief review on the market trends in automotive industry is provided to put our case study in section IV into context.

Despite significant benefits, the internal combustion engine vehicle (ICEV) suffers from low efficiency and has environmentally harmful exhaust gas emissions. In response to these issues, car manufacturers are under pressure to develop energy-efficient and environmentally-compatible vehicles driven by government regulation, e.g. the Clean Air Act 1993 and zero-emission vehicle mandates 1990 were introduced in the USA.

To replace a mature technology such as the ICEV, the alternative must provide significant advantages. Although General Motors successfully launched their first modern production battery-powered electric vehicle (BEV) named EV1 in 1996, rare intermission for fast refuelling systems and high pressure from the oil industry company and car manufactures [16, 17], together with weak consumer and federal government pressures [17] saw the car discontinued in 1999 and subsequently removed from the roads in 2003.

While the BEV has been in existence for over a century, it has never seen widespread use in modern traffic settings hence remains largely untested in a realistic operational environment. Despite the offer of reduced dependency on fossil fuel and less maintenance and operating cost, the high initial cost of the battery, its heavy weight compared to gasoline, short driving range per charge, slow recharging, sluggish performance [16] reduced passenger and cargo space [18] has further declined the interest in BEVs. A confluence of technological advances, improved market conditions and economic and political factors are required to transform current BEVs into an attractive choice for consumers [19].

Fuel cells (FCs) are claimed to offer a promising alternative to conventional batteries [20-23]. FCs have the potential to provide a high efficiency while greatly reducing tailpipe emissions [24], in addition to fast refuelling. However, several technical issues must be addressed before FCs could become a realistic power source for mass produced vehicles. The storage of hydrogen in compressed tanks is a particular concern; 
hydrogen gas storage requires pressures and temperatures in excess of $34 \mathrm{MPa}$ and $-253{ }^{\circ} \mathrm{C}$, which can present critical safety issue [25-28]. In addition the infrastructure needed for generation and transportation of hydrogen is virtually nonexistent [29]. High energy-cost per kW for effective hydrogen generation as well as expensive platinum catalyst makes fuel cells very expensive compared to other batteries. The performance of current systems deteriorates after $\approx 1000 \mathrm{~h}$ in stationary applications, and the expected lifetime in automotive applications is even shorter [26], which adds a further challenge to FC powered EVs.

HEVs have become the principal competitors of BEVs [30]. HEVs offer the combination of the benefit of the two matured technologies of the ICE and the electric generator/motor (EGM). Furthermore, all required components are readily available, taking advantage of advanced electric motor drives [31]. With this inbuilt dual function, the system can be easily configured to obtain improvements in system efficiency and/or reduced emissions.

Current commercial HEVs are loosely classified as micro, mild, medium or full according to the degree of hybridization and the power rating and operating voltage of the electric components as shown in Table 3 . The battery is not normally charged from an external power source. Additionally, the battery normally requires a high power rating together with a relatively low energy capacity, which can be challenging for conventional batteries. An RFB can readily achieve these characteristics, as the energy and power components are decoupled.

TABLE 3

Classification OF HEVs ACCORDING TO THE BATTERy POWER RATING

\begin{tabular}{|c|c|c|c|c|c|c|}
\hline Electrical & Mech. & $\begin{array}{c}\text { Volt. } \\
/ \mathbf{V}\end{array}$ & $\begin{array}{c}\text { Power } \\
/ \mathbf{k W}\end{array}$ & $\begin{array}{c}\text { Energy } \\
/ \mathbf{k W ~ h}\end{array}$ & Re-generative & $\begin{array}{c}\text { AER } \\
\text { Possible }\end{array}$ \\
\hline $\begin{array}{c}\text { Micro- } \\
\text { Smart Fortwo }\end{array}$ & Start-Stop & $\approx 12$ & $\approx 6$ & $\approx 0.25$ & Minimal & No \\
\hline $\begin{array}{c}\text { Mild- } \\
\text { Chevy } \\
\text { Silverado }\end{array}$ & Start-Stop & $\approx 42$ & $\approx 13$ & $\approx 0.3$ & Moderate & Minimal \\
$\begin{array}{c}\text { Medium- } \\
\text { Honda Insight }\end{array}$ & Parallel & $\approx 114$ & $\approx 25$ & $\approx 1.0$ & Full & Moderate \\
\hline $\begin{array}{c}\text { Full- } \\
\text { Toyota Prius }\end{array}$ & $\begin{array}{c}\text { Series- } \\
\text { parallel or } \\
\text { Complex }\end{array}$ & $>200$ & $\approx 50$ & $\approx 1.5$ & Full & Full \\
* adapted from [18,30,32, 33] & \multicolumn{7}{|l}{}
\end{tabular}

As oil and gas supplies diminish and electricity generation shift to alternative sources, it is likely that there will also be a shift in HEV design towards the plug-in HEV (PHEV) [34] having a smaller ICE, larger EMG and larger batteries that need to be charged from an external source. The rapid recharging benefit offered by RFBs may therefore become attractive.

\section{CASE Study: V-RFB Powered SERIES HeV}

RFB research has in the main focused on devices for largescale energy storage for grid load levelling applications. Several RFBs are currently produced commercially including the V-RFB patented by Skyllas-Kazacos et al. [35-37].
Significant research on V-RFBs is on-going in our laboratory to optimize the chemistry and mechanical design, develop mathematical models, and research into battery management systems [7, 38-41]. Batteries of different sizes and configurations have been developed and tested. But for the purpose of this study an un-optimized $100 \mathrm{~cm}^{2}$ allvanadium RFB unit cell (see Fig. 3) has been constructed according to the specifications given in Table 4. A typical charge and discharge voltage characteristic with a constant current of $10 \mathrm{~A}$ is shown in Fig. 4 and the single-cycle chargedischarge voltage characteristic is shown in Fig. 5. The redox reactions during discharging of V-RFB are as follows:

Negative electrode: $\mathrm{V}^{3+}+\mathrm{e}^{-} \rightarrow \mathrm{V}^{2+}$

Positive electrode: $\mathrm{VO}^{2+}+2 \mathrm{H}^{+}+\mathrm{e}^{-} \rightarrow \mathrm{VO}_{2}{ }^{+}+\mathrm{H}_{2} \mathrm{O}$

where $\mathrm{V}^{3+}$ and $\mathrm{V}^{2+}$ indicate the oxidation states of vanadium species.

It was observed that the average power discharged is approximately $11.0 \mathrm{~W}$ and the discharged energy using 500 $\mathrm{mL}$ of reactants is $7.3 \mathrm{~W} \mathrm{~h}$. The charging power and energy are approximately $16.9 \mathrm{~W}$ and $11.3 \mathrm{~W} \mathrm{~h}$, respectively. This suggests energy, power and voltage efficiencies of about 65 $\%$, excluding power losses associated with the pumps. Improved performance can be achieved by improving the solubility of vanadium using modified electrolytes, improved packaging, and optimised cell design to reduce spacing between the plates and improved heat transfer.

TABLE 4

\begin{tabular}{|l|l|}
\multicolumn{1}{c}{ SPECIFICATION OF A LABORATORY $100 \mathrm{CM}^{2} \mathrm{~V}^{3+} / \mathrm{V}^{4+} \mathrm{M}$ RFB } \\
\cline { 2 - 2 } \multicolumn{1}{c|}{ Parameter } \\
\hline Cell stack body & Polyvinylchloride polymer \\
\hline Electrode compartment & $100 \mathrm{~cm}^{2}$ \\
\hline Single stack dimension & $15 \mathrm{~cm} \mathrm{x} 15 \mathrm{~cm} \mathrm{x} 4 \mathrm{~cm}$ \\
\hline Membrane & Nafion ${ }^{\mathbb{B}} 1135$ \\
\hline Porous layer & $\begin{array}{l}\text { Carbon felt electrode (Sigratherm GFA5) } \\
\text { with effective porosity } 0.68 \pm 0.07\end{array}$ \\
\hline Reservoir volume & $250 \mathrm{~mL}$ each \\
\hline Vanadium concentration & $1.4 \mathrm{M}\left(\mathrm{V}^{3+} / \mathrm{V}^{4+}\right.$ dissolved in $\left.4 \mathrm{M} \mathrm{H}_{2} \mathrm{SO}_{4}\right)$ \\
\hline Current & Constant current of $10 \mathrm{~A}$ \\
\hline Volumetric flow rate & $100 \mathrm{~cm}^{3} \mathrm{~min}^{-1}$ through each compartment \\
\hline
\end{tabular}

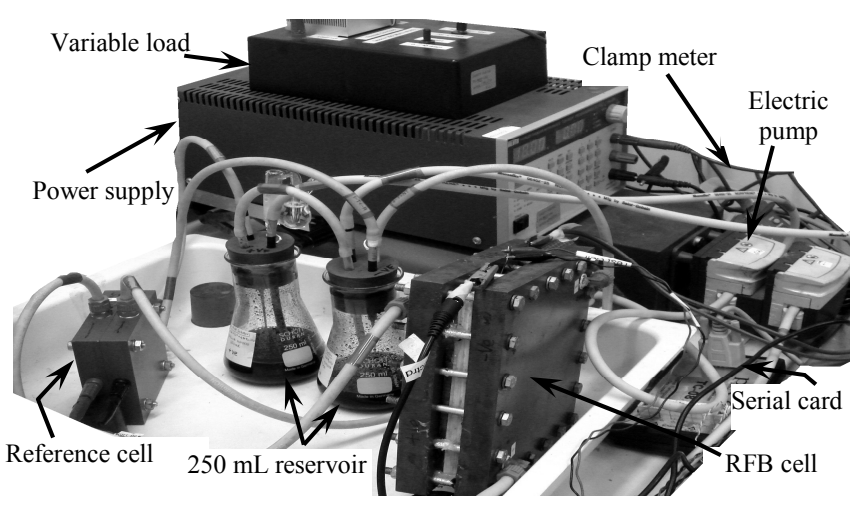

Fig. 3. A unit cell laboratory, $100 \mathrm{~cm}^{2}$ electrode all-vanadium RFB. Modified from a laboratory system by Re-Fuel Technology Ltd 


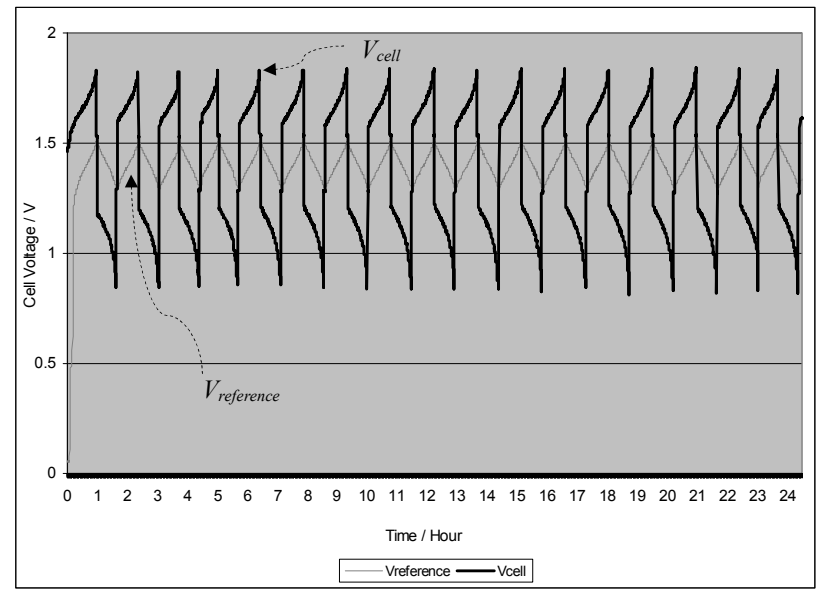

Fig. 4. A typical voltage charge-discharge characteristic of $100 \mathrm{~cm}^{2}$ laboratory V-RFB at maximum charge and discharge currents of $10 \mathrm{~A}$.

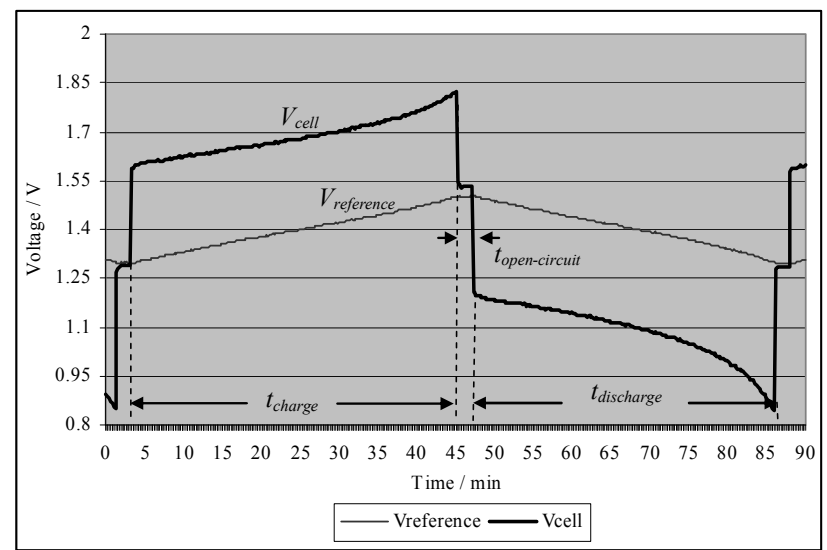

Fig. 5. Single-cycle of voltage charge and discharge characteristic of $100 \mathrm{~cm}^{2}$ laboratory V-RFB at maximum charge and discharge currents of $10 \mathrm{~A}$.

As a case study, the size of a scaled-up V-RFB, suitable for use on the University of Southampton series hybrid vehicle described in [6] and shown in Fig. 6 can be estimated.

The vehicle is capable of a top speed of $70 \mathrm{mph}$ and a pure electric range of $60 \mathrm{~km}$ and an extended range of $300 \mathrm{~km}$. To achieve this performance a $72 \mathrm{~V}, 110 \mathrm{~A} \mathrm{~h}, 300 \mathrm{~A}$ (maximum) lithium-ion battery was used. The lithium-ion battery shown in Fig. 6 weighed $60 \mathrm{~kg}$ and had a volume of $96 \mathrm{~L}$. A similar conventional lead-acid battery, also shown in the Fig. 6, weighed $250 \mathrm{~kg}$ and had a volume of approximately $300 \mathrm{~L}$.

We can scale-up the size of the experimental cell in Fig. 5 to match the above requirements. Note that the calculation will exclude the packaging and scaling-up uses linear relationships as a first approximation. The area of the electrodes is proportional to the current and hence the cross-sectional area of the battery needs to be 30 times bigger, i.e. it needs to be $3000 \mathrm{~cm}^{2}$, which is approximately $55 \mathrm{~cm} \mathrm{x} 55 \mathrm{~cm}$. The voltage determines the number of cells in series, and given that the average voltage per cell is approximately $1.1 \mathrm{~V}$, the total number of required cells is 66 . Given that the active thickness per cell is $1 \mathrm{~cm}$, the total length of a bipolar cell stack with retaining end frames is estimated to be about $70 \mathrm{~cm}$ and hence the total volume of the cell stack is estimated to be 212 litres.



Fig. 6. Southampton University HEV showing lithium-ion battery and equivalent conventional lead-acid battery

The volume of the reactants can be estimated using Faraday's laws of electrolysis:

$$
q=\frac{z F V \Delta c}{M}
$$

Where $q$ is the total stored charge, $z$ is the number of electrons transferred during the redox reaction which is 1 for the V-RFB, $F$ is Faraday constant (26.8 $\left.\mathrm{A} \mathrm{h} \mathrm{mol}^{-1}\right), V$ is the volume of the reactants, $\Delta c$ is the reactant concentration (approximately $1 \mathrm{~mol} \mathrm{~L}^{-1}$ for the test cell) and $M$ is the molar mass of the reactant $\left(50.94 \mathrm{~g} \mathrm{~mol}^{-1}\right.$ for vanadium $)$. This results in a theoretical charge density $q / V$ of $27 \mathrm{~A} \mathrm{~h} \mathrm{~L}^{-1}$ or a volumetric energy storage capability of approximately $30 \mathrm{~W} \mathrm{~h}$ $\mathrm{L}^{-1}$. In practice, the energy density range is typically $20-35 \mathrm{~W}$ $\mathrm{h} \mathrm{L}^{-1}$ depending on electrolyte concentration. Assuming an energy density of $25 \mathrm{~W} \mathrm{~h} \mathrm{~L}^{-1}$, the volume of the electrolyte needed for the $110 \mathrm{~A} \mathrm{~h}, 72 \mathrm{~V}$ battery cell stack is approximately 317 litres. The total volume and mass of the unoptimised V-RFB needed for the case study vehicle are therefore estimated to be 424 litres and $400 \mathrm{~kg}$, respectively. This is much larger than the lithium-ion battery and about 40 $\%$ larger in volume than the conventional lead-acid.

A Battery Powered Electric Golf Cart has been developed at UNSW, using 40-liters of $1.85 \mathrm{M}$ an all-vanadium RFB; a driving range of $17 \mathrm{~km}$ off-road was obtained [42], which suggests that the energy density of an optimised all-vanadium RFB could approach that of lead-acid, with the added advantage of rapid recharging by electrolyte replacement.

\section{RFB CHALlENGES AND Future ProspeCtS}

Despite the advantages offered by the RFB, the technology is still emerging and has a long way to go before it can meet the demands of automotive industries. Some of the materials used in RFBs, e.g. vanadium, electrolytes require careful sourcing. The relatively low specific energy of $25-35 \mathrm{~W} \mathrm{~h}$ $\mathrm{kg}^{-1}$ of RFB as well as energy management of RFBs, are also an important areas for development.

Further research is needed to improve the performance, and 
overall control and management of RFBs, and reduce the cost. Higher power and energy densities can be achieved by optimizing the chemistry and mechanical design of the battery. Using modified electrolytes it is possible to increase the molar concentration of the reactants and hence the energy density. Current and power density can be improved by better heat transfer and flow characteristics. Three-dimensional, closely spaced electrodes could further enhance the power density of the cell. Research is also needed to improve the packaging and safety of RFBs to suit vehicle applications.

\section{CONCLUSION}

Current redox flow batteries can match lead-acid in terms of energy density but significantly lower than Li-ion systems. But they have the advantage of rapid charging by electrolyte replacement which makes them attractive for use on electric vehicle or hybrid electric vehicles. Golf-cart, forklift truck, and in-town-short distance family car could find this beneficial. If infrastructure is in place, long journey distance would be possible. Another feature of RFBs that makes them attractive for EV and HEV applications is the separation in terms of physical location and sizing, of the energy and power components. This adds a degree of flexibility that allows the optimization of the power and energy components for specific vehicle configuration and performance. Further research is needed to improve the performance and engineering of RFB system.

\section{ACKNOWLEDGMENT}

The authors are grateful to Re-Fuel Technology Ltd, Finchampstead, Wokingham, UK for provision of equipment and to Peter Ridley for discussions on vanadium redox flow battery technology.

\section{REFERENCES}

[1] G. T. Hayward, "BP statistical review of world energy," 2008, pp. 1-48.

[2] S. Haldenbilen, "Fuel price determination in transportation sector using predicted energy and transport demand," Energy Policy, vol. 34, pp. $3078-3086,2006$.

[3] A. Schafer and D. G. Victor, "The future mobility of the world population," Transportation Research Part A, vol. 34, pp. 171-205, 2000.

[4] C. J. Campbell; and J. H. Laherrère, "The end of cheap oil," Scientific American, vol. 278, pp. 78-83, 1998.

[5] Cambridge Energy Research Associates Inc, "Peak oil theory - "World running out of oil soon" - is faulty; could distort policy \& energy debate,"Available:http://www.cera.com/aspx/cda/publicl/news/pressRe leases/pressReleaseDetails.aspx?CID $=8444$ Retrieved by November 14, 2006, accessed on July 10, 2008

[6] D. Doerffel and S. Abu Sharkh, "System modeling and simulation as a tool for developing a vision for future hybrid electric vehicle drivetrain configurations," in Vehicle Power and Propulsion Conference, 2006. VPPC '06. IEEE, 2006, pp. 1-6.

[7] C. Ponce-de-León, A. Frías-Ferrer, J. González-García, D. A.Szánto, and F. C. Walsh, "Redox flow cells for energy conversion," Journal of Power Sources, vol. 160, pp. 716-732, 2006.

[8] M. Skyllas-Kazacos, "Novel vanadium chloride/polyhalide redox flow battery," Journal of Power Sources, vol. 124, pp. 299-302, 2003.

[9] T. Shigematsu, T. Kumamoto, H. Deguchi, and T. Hara, "Applications of a vanadium redox-flow battery to maintain power quality "
Transmission and Distribution Conference and Exhibition 2002: Asia Pacific. IEEE/PES, vol. 2, pp. 1065- 1070.

[10] L. Joerissen, J. Garche, C. Fabjan, and G. Tomazic, "Possible use of vanadium redox-flow batteries for energy storage in small grids and stand-alone photovoltaic systems," Ulm, Germany, 2004, pp. 98-104.

[11] T. Kaizuka and T. Sasaki, "Evaluation of control maintaining electric power quality by use of rechargeable battery system," in Power Engineering Society Winter Meeting, 2001. IEEE, 2001, pp. 88-93 vol.1.

[12] S. A. Lone and M. u.-D. Mufti, "Integrating a redox flow battery system with a wind-diesel power system," in Power Electronics, Drives and Energy Systems, 2006. PEDES '06. International Conference on, 2006, pp. 1-6.

[13] S. Miyake and N. Tokuda, "Vanadium redox-flow battery for a variety of applications," in Power Engineering Society Summer Meeting, 2001. IEEE, 2001, pp. 450-451 vol.1.

[14] N. Tokuda, T. Kanno, T. Hara, T. Shigematsu, Y Tsutsui, A. Ikeuchi, T Itou, and T. Kumamoto., "Development of redox flow battery system," SEI Technical Review June 2000, vol. No. 50, pp. 88-94, 2000.

[15] S. M. Abu Sharkh and G. Griffiths, "Energy storage systems for unmanned underwater vehicles," Underwater Technology, vol. 25, pp. $143-148,2002$.

[16] B. D. McNicol, D. A. J. Rand, and K. R. Williams, "Fuel cells for road transportation purposes -- yes or no?," Journal of Power Sources, vol. 100 , pp. 47-59, 2001

[17] J. Mader, "Battery powered vehicles : Don't rule them out," Available: www.engin.umich.edu/dept/che/research/schwank/people/Papers/Batte ryPower.pdf Retrieved by November 16, 2006, accessed on September 03, 2008.

[18] C. C. Chan, "The state of the art of electric, hybrid, and fuel cell vehicles," Proceedings of the IEEE, vol. 95, pp. 704-718, 2007.

[19] R. P. Joshi and A. P. Deshmukh, "Hybrid electric vehicles: The next generation automobile revolution," in Electric and Hybrid Vehicles, 2006. ICEHV'06. IEEE Conference on, 2006, pp. 1-6.

[20] B. Cook, "Introduction to fuel cells and hydrogen technology," Engineering Science And Education Journal, pp. 205-216, 2002.

[21] J. A. Smith, M. H. Nehrir, V. Gerez, and a. S. R. Shaw, "A broad look at the workings, types, and applications of fuel cells," Power Engineering Society Summer Meeting 2002, IEEE, vol. 1, pp. 70-75, 2002.

[22] S. D. Pathak, J.N. Rangarajan, J. Choudhury, S.R. Prakash, R., "Development of prototype phosphoric acid fuel cell pick-up electric vehicle," in ICEHV' 06 . IEEE Conference, 2006, pp. 1-4.

[23] M. C. Pera, D. Hissel, and J. M. Kauffmann, "Fuel cell systems for electrical vehicles," in Vehicular Technology Conference, 2002. VTC Spring 2002. IEEE 55th, 2002, pp. 2097-2102 vol.4.

[24] S. Dhameja, Electric vehicle battery systems. Woburn: Newnes Press, 2002.

[25] X. He, T. Maxwell, and M. Parten, "Development of a hybrid electric vehicle with a hydrogen-fueled IC engine," Vehicular Technology, IEEE Transactions on, vol. 55, pp. 1693-1703, 2006.

[26] S. G. Chalk and J. F. Miller, "Key challenges and recent progress in batteries, fuel cells, and hydrogen storage for clean energy systems," Journal of Power Sources, vol. 159, pp. 73-80, 2006.

[27] J. Larminie and J. Lowry, Electric vehicle technology explained. West Sussex: John Wiley \& Sons, Ltd, 2003.

[28] I. Husain, Electric and hybrid vehicles: Design fundamentals. Boca Raton, Florida: CRC Press, 2003.

[29] J. J. Romm, The hype about hydrogen: Fact and fiction in the race to save the climate. Washington DC: Island Press, 2004.

[30] O. Bitsche and G. Gutmann, "Systems for hybrid cars " Journal of Power Sources vol. 127, pp. 8-15, 2004.

[31] C. C. Chan and Y. S. Wong, "Electric vehicles charge forward," Power and Energy Magazine, IEEE, vol. 2, pp. 24-33, 2004.

[32] S. M. Lukic, C. Jian, R. C. Bansal, F. Rodriguez, and A. Emadi, "Energy Storage Systems for Automotive Applications," Industrial Electronics, IEEE Transactions on, vol. 55, pp. 2258-2267, 2008.

[33] E. Karden, S. Ploumen, B. Fricke, T. Miller, and K. Snyder, "Energy storage devices for future hybrid electric vehicles," Journal of Power Sources, vol. 168, pp. 2-11, 2007

[34] T. E. Lipman and M. A. Delucchi, "A retail and lifecycle cost analysis of hybrid electric vehicles," Transportation Research Part D: Transport and Environment, vol. 11, pp. 115-132, 2006.

[35] M. Skyllas-Kazacos and R. G. Robins, "All Vanadium Redox Battery." vol. 849094, U. Patent, Ed. USA, 1986. 
[36] P. Zhao, H. Zhang, H. Zhou, J. Chen, S. Gao, and B. Yi, "Characteristics and performance of $10 \mathrm{~kW}$ class all-vanadium redoxflow battery stack," Journal of Power Sources, vol. 162, pp. 14161420, 2006.

[37] M. Skyllas-Kazacos, D. Kasherman, D. R. Hong, and M. Kazacos, "Characteristics and performance of $1 \mathrm{~kW}$ UNSW vanadium redox battery," Journal of Power Sources, vol. 35, pp. 399-404, 1991.

[38] A. A. Shah, M. J. Watt-Smith, and F. C. Walsh, "A dynamic performance model for redox-flow batteries involving soluble species," Electrochimica Acta, vol. 53, pp. 8087-8100, 2008.

[39] D. Pletcher, Z. Hantao, G. Kear, C. T. J. Low, F. C. Walsh, and R. G. A. Wills, "A novel flow battery - a lead-acid battery based on an electrolyte with soluble lead (II). Part VI. studies of the lead dioxide positive electrode," Journal of Power Sources, vol. 180, pp. 630-634, 2008.

[40] C. Ponce-de-Leon, G. W. Reade, I. Whyte, S. E. Male, and F. C. Walsh, "Characterization of the reaction environment in a filter-press redox flow reactor," Electrochimica Acta, vol. 52, pp. 5815-5823, 2007.

[41] G. J. W. Radford, J. Cox, R. G. A. Wills, and F. C. Walsh, "Electrochemical characterisation of activated carbon particles used in redox flow battery electrodes," Journal of Power Sources, vol. 185, pp 1499-1504, 2008

[42] M. Skyllas-Kazacos, "Recent progress with the USNW vanadium battery"Available:http://www.arizonaenergy.org/Analysis/FuelCell/Va nadium\%20Battery/recent_progress_with_the_unsw_va.htm, Retrieved on February 24, 2008, accessed on July $\overline{07}, 2008$. 